Kelaniya Journal of Human Resource Management

Volume 11, Number 01 - January 2016

DOI: http://doi.org/10.4038/kjhrm.v11i1.26

\title{
Factors Influencing Employee Motivation among Non-Managerial Staff in Hotel Sector, Sri Lanka
}

\author{
Romita Devi De Silva ${ }^{1}$ and K. K. Thilakasiri ${ }^{2}$ \\ ${ }^{1}$ Department of Management and Finance, \\ General Sir John Kotelawala Defense University, Sri Lanka \\ ${ }^{2}$ Department of Accountancy, University of Kelaniya, Sri Lanka \\ 1deviromita@yahoo.com, ${ }^{2}$ ktilakasiri@kln.ac.lk
}

\begin{abstract}
Motivation plays a significant role to attract, maintain and retain an effective workforce which helps to achieve the organization goals. The success of an organization highly depends on the available effective workforce. However, all employees do not have the same expected factors of motivation which is depend on the preferences of employees. So, management needs to choose right strategy and factors in order to motivate their effective staff. This study is focus to explore the significant factors which influence on employees' motivation among the non-managerial staff in the hotel sector. There is high demand of hotel staff due to increasing number of tourist in Sri Lanka. This study has been conducted among 100 non-managerial employees who are working in 5 star hotels in Sri Lanka. The finding of the study revealed that workload, service charge, bonus, salary, flexible rule \& regulation and relationship with colleague are top most significant factors of motivation among the non-managerial staff in the hotel. As per the findings, involvement in decision making and promotion are not statistically significant factors of motivation of non-managerial hotel staff.
\end{abstract}

Keywords: Motivation, Factors of Motivation, Non Managerial Staff, Hotel Industry

\section{Introduction}

Sri Lanka has been ranked $63^{\text {rd }}$ in tourism out of 141 countries in the world. Tourism is the third largest foreign exchange earner in the country and also helps to reduce the unemployment rate. According to World Travel and Tourism council report (2015) the total contribution of tourism in Sri Lanka 
is LKR 1,067.4bn (11.1\% of GDP) in 2014 and total contribution to employment is 819,500 jobs ( $10 \%$ of total employment). Sri Lanka achieved 2.05 million tourists in 2016. Hotel takes main role in the tourism sector by providing accommodation, meals, and other guest services for travelers and tourists. However, there is a shortage of staff in hotel sector in Sri Lanka. Many skilled hotel employees are working in abroad because of high pay. According to Deva, the board of Directors, more than 2200 new staff will be requiring for upcoming 5 star hotels in Colombo (Senewiratne, 2016). Therefore, it is necessary to motivate and trained the available hotel staff in order to retain them in the home country. Motivation takes an important role in the success of an organization. There are various factors and strategies of motivation at workplace in order to retain productive staff. It can influence to change the behavior of the employee. The success of an organization is highly depends on the available staff. Generally, motivated employees are more productive which help to achieve the organization goals. Focus on the right motivation strategies will help to reduce absenteeism and turnover which will lead to retain effective staff.

\section{Problem Statement}

According to chairman, Paddy Withana of SLTDA, Sri Lanka is targeting 4.5 million tourist arrivals in 2020 (Jayalal, 2016). So, it is necessary to increase number of hotels and hotels room in order to achieve the estimated target. At present, total available hotel room strength is 28,426 and there are 11,645 rooms in the pipeline from the already approved and ongoing projects (Miththapala, 2015). Based on WTTC report (2015), the total contribution of Travel \& Tourism to employment has fallen to 800,000 jobs ( $9.7 \%$ of total employment) in 2015 from 819,500 jobs (10.0\% of total employment) in 2014. It also reveals that Travel \& Tourism forecast to support 943,000 jobs (11.1\% of total employment) an increase of $1.7 \%$ pa over the period by 2025 . These figure shows that there is a huge demand of human resource in the hotel sector. Therefore, it is necessary to investigate the factors influencing employee motivation in hotel section in order to retain them.

\section{Objectives of the Study}

The main aim of this study is to explore the factors which influence on employees' motivation among the non-managerial staff in hotel sector. 
Researcher has developed few specific objectives in order to achieve the aim of the study as:

- To determine the significant factors which influence motivation among the Non Managerial staff in hotel sector.

- To provide recommendations based on the finding of the study in order to motivate Non Managerial hotel staff.

\section{Significant of the Study}

The findings of the study might be useful to the decision maker by considering that motivation plays an important role in the hotel sector. The greater demand for hotel staff in Sri Lanka justifies the need for motivating and retaining hotel staff. Thus, the recommended approach derived from the result of the study will be able to motivate and retain hotel staff in better way. This study might be guided on what factors should be emphasized by management in order to motivate non-managerial hotel staff.

\section{Literature Review}

Human resource is the most important asset in any organization. The sustainability and effectiveness of the organization is highly depends on the human resources. In order to utilize the competencies of the human resource, it is necessary to identify the employee needs. Those identify needs can link with motivation. Motivation at work means that to provide the needs of employees what they really want from work. Here, motivation can use as driving force that makes employees to perform better.

\subsection{Factors of Motivation}

Motivation is one of the important ways to utilize, maintain and retain the employees. In order to motivate employees, it is necessary to identify what are the factors which make them to motivate at workplace. Velnampy (2007) found that salary is most significant factor of motivation followed by friendly working atmosphere and interpersonal relationships in private sector employees. $42.7 \%$ employees responded that monetary compensation is most important factor which influence on their motivation and $31.3 \%$ responded it is important factor of motivation (Gichure, 2014). However based on the 
study conducted by Safiullah (2015), pay and incentive is the least important factor of motivation spotted in ranked 6th. Author also mentioned that opportunity for career growth and development is most important factor of motivation followed by job security and challenging \& interesting task. Ajang (2007) also ranked salary is in 4th position while job satisfaction is in $1^{\text {st }}$ position, promotion is in $2^{\text {nd }}$ and recognition is in $3^{\text {rd }}$ among the top 5 factors of motivation. Jasmi (2012) found that employees are motivated when they received more right, duties and responsibilities. Researcher also mentioned that majority of the respondents are not satisfied on decision making as they are not encourage to take decision. As per the finding of the research conducted by Gupta \& Subramanian (2014) main factors which effect on motivation are training, workloads and salary. Ismajli, Zekiri \& et al, 2015 revealed that salary, professional advancement and promotion are the most important factors of motivation.

\section{Research Methodology}

Descriptive study has been adopted for this study. Researchers believe that it is appropriate to used descriptive study because this study is about finding out the factors which influence on employee motivation.

\subsection{Population of the study}

Population is a set of people or object consider for the study. For this study, population of the study is all the non-managerial staff among the selected 5 star hotels from 3 different places in Sri Lanka.

\subsection{Sample size and sampling}

Sample size refers to the number of elements selected from the population. A unit of analysis for this study is based on non-managerial staff working in the selected 5 star hotels in Sri Lanka. Sample of 100 respondents were selected through a simple random sampling method. 


\subsection{Data Collection}

Questionnaire method is used in order to collect the primary data of the study. Researcher used open ended, close ended and rating scale in order to collect information from the respondents. The questionnaire was divided into two sections. The first section was designed to analyze the demographic information of the respondents and second section consist the questions based on the motivational factors. Five point Likert scale representing strongly disagree, disagree, neutral, agree, and strongly agree is used to measure the level of preference of the respondents. Secondary data has been collected from the review of literatures from various journal articles, conference papers, books, newspapers and website.

\subsection{Data Analysis}

Factor analysis was used to identify the most significant factors which influence employee motivation of non-managerial hotel staff. The results of the analysis were presented in form of tables.

\section{Data Analysis and Presentation}

\subsection{Demographic Factors}

Questionnaire was distributed among 100 non managerial staffs who are working in 5 star hotels. The sample represents 21 females and 79 males. Only 16 respondents are married and 84 respondents are unmarried. Study shows that majority (83\%) of the respondents' ages lies between 21 to 30 ages, only $12 \%$ are below 21 ages and $5 \%$ are above 30 ages. In case of work experience of employment, study found that $82 \%$ of the respondents are in less than 1 year period of employment and 18 respondents are above 1 year to maximum 5 years. 


\subsection{Reliability Statistics}

Table 01: Reliability test

\begin{tabular}{|c|c|c|}
\hline Cronbach's Alpha & Cronbach's Alpha Based on Standardized Items & N of Items \\
\hline .866 & .868 & 19 \\
\hline
\end{tabular}

Reliability test has done by using 19 items relating to employee motivation. Generally, Cronbach's alpha reliability coefficient ranges are between 0 and 1. A high Cronbach Alpha value of 0.866 indicates good internal consistency of the items in the scale.

\subsection{Sample Adequacy and validity test}

\section{Table 02: KMO and Bartlett's test}

\begin{tabular}{|c|c|c|}
\hline \multicolumn{2}{|c|}{ Kaiser-Meyer-Olkin Measure of Sampling Adequacy. } & .664 \\
\hline Bartlett's Test of Sphericity & Approx. Chi-Square & 1413.465 \\
\hline & df & 171 \\
\hline & Sig. & .000 \\
\hline
\end{tabular}

Kaiser-Meyer-Olkin (KMO) test is used to measure sample adequacy. Based on the table 4.2, the KMO value is 0.664 which is higher than the recommended acceptable value 0.5 . Therefore, sample use for this study is adequate. Bartlett's Test is done to check the validity and suitability of data collected to the problem being addressed through the study. The significance value is 0.000 which is less than the recommended value 0.05 . Therefore, it indicates that strength of the relationship among the variables is high. 


\subsection{Factor Extraction}

Table 03: Factor Extraction

\begin{tabular}{|c|c|c|c|c|c|c|c|}
\hline \multirow{2}{*}{ Component } & \multicolumn{3}{|c|}{ Initial Eigenvalues } & \multicolumn{3}{|c|}{ Extraction Sums of Squared Loadings } & \multirow{2}{*}{$\begin{array}{c}\text { Rotation Sums } \\
\text { of Squared } \\
\text { Loadings } \\
\text { Total }\end{array}$} \\
\hline & Total & $\%$ of Variance & Cumulative $\%$ & Total & $\%$ of Variance & Cumulative $\%$ & \\
\hline 1 & 5.771 & 30.374 & 30.374 & 5.771 & 30.374 & 30.374 & 3.776 \\
\hline 2 & 2.688 & 14.148 & 44.522 & 2.688 & 14.148 & 44.522 & 3.866 \\
\hline 3 & 2.203 & 11.593 & 56.114 & 2.203 & 11.593 & 56.114 & 3.635 \\
\hline 4 & 1.741 & 9.164 & 65.278 & 1.741 & 9.164 & 65.278 & 4.151 \\
\hline 5 & 1.463 & 7.700 & 72.978 & 1.463 & 7.700 & 72.978 & 1.790 \\
\hline 6 & 1.113 & 5.856 & 78.834 & 1.113 & 5.856 & 78.834 & 3.034 \\
\hline 7 & .825 & 4.344 & 83.178 & & & & \\
\hline 8 & .616 & 3.240 & 86.418 & & & & \\
\hline 9 & .552 & 2.907 & 89.325 & & & & \\
\hline 10 & .384 & 2.022 & 91.346 & & & & \\
\hline 11 & .355 & 1.869 & 93.215 & & & & \\
\hline 12 & .294 & 1.547 & 94.762 & & & & \\
\hline 13 & .242 & 1.274 & 96.037 & & & & \\
\hline
\end{tabular}


Kelaniya Journal of Human Resource Management

Volume 11, Number 01 - January 2016

\begin{tabular}{|c|c|c|c|c|c|c|c|}
\hline \multirow{2}{*}{ Component } & \multicolumn{3}{|c|}{ Initial Eigenvalues } & \multicolumn{2}{c|}{ Extraction Sums of Squared Loadings } & $\begin{array}{c}\text { Rotation Sums } \\
\text { of Squared } \\
\text { Loadings }\end{array}$ \\
\cline { 2 - 8 } & Total & $\%$ of Variance & Cumulative \% & Total & \% of Variance & Cumulative \% & Total \\
\cline { 2 - 8 } 14 & .210 & 1.107 & 97.144 & & & \\
15 & .162 & .851 & 97.995 & & & \\
16 & .133 & .702 & 98.698 & & & \\
17 & .106 & .559 & 99.257 & & & \\
18 & .083 & .437 & .307 & 100.000 & & & \\
19 & .058 & & & & & & \\
\end{tabular}

Extraction Method: Principal Component Analysis.

a. When components are correlated, sums of squared loadings cannot be added to obtain a total variance.

Exploratory factor analysis is used by considering principal component as the extraction and Varimax as the rotation method. The table 4.3 shows the actual factors that were extracted. There are six important factors which has the Eigenvalue is greater than 1. Factor one account more variance $30.374 \%$ of the variability in all 19 variables. 


\subsection{Rotated component matrix}

Table 04: Rotated component matrix

\begin{tabular}{|c|c|c|c|c|c|c|}
\hline & \multicolumn{6}{|c|}{ Component } \\
\hline & 1 & 2 & 3 & 4 & 5 & 6 \\
\hline SCR & .963 & & & & & \\
\hline BNS & .959 & & & & & \\
\hline SLY & .949 & & & & & \\
\hline FRR & & .955 & & & & \\
\hline CDP & & .906 & & & & \\
\hline $\mathrm{RRG}$ & & .738 & & & & \\
\hline WHR & & .658 & & & & \\
\hline RWC & & & .949 & & & \\
\hline RWS & & & .867 & & & \\
\hline RSN & & & .810 & & & \\
\hline WLD & & & & 1.025 & & \\
\hline WPR & & & & .861 & & \\
\hline EST & & & & .849 & & \\
\hline TND & .396 & & & & .770 & \\
\hline IDM & & & & & -.585 & \\
\hline PRO & & .446 & & & -.551 & \\
\hline RNR & & & .343 & .325 & .542 & \\
\hline PAP & & & & & & .895 \\
\hline HNS & & & & & & .885 \\
\hline
\end{tabular}

Extraction Method: Principal Component Analysis.

Rotation Method: Promax with Kaiser Normalization. ${ }^{\mathrm{a}}$

a. Rotation converged in 5 iterations.

\section{Where;}

$\mathrm{SCR}=$ Service charge, $\mathrm{BNS}=$ Bonus, $\mathrm{SLY}=$ salary, $\mathrm{FRR}=$ Flexible rule $\&$ regulation, $\mathrm{CDP}=$ Career development programs, $\mathrm{RRG}=$ Reward \& Recognition, WHR $=$ Working hours, RWC $=$ Relationship with colleague, $\mathrm{RWS}=$ Relationship with Supervisor, RSN = Relationship with subordinate, WLD = Workload, WPR = Work pressure, EST = Empowerment \& Status, TND = Training \& Development, $\mathrm{IDM}=$ Involvement in decision making, $\mathrm{PRO}=$ Promotion, $\mathrm{RNR}=$ Right $\&$ Responsibility, PAP = Performance Assessment Policy, HNS = Health \& Safety 
Six factors were constructed using factor analysis. Rotated component matrix shows the factor loadings for each variable. It indicates the correlation between each of the variables and the estimated components. There are three items as SCR, BNS, SLY are strongly loaded in factor 1. Factor 2 is strongly comprised of 4 items as WHR, RRG, CDP and FRR ranging from 0.658 to 0.955 . The items in factor 3 are RSN, RWS and RWC ranging from 0.810 to 0.949. Factor 4 is loaded with 3 items as EST, WPR, and WLD. Factor 5 is loaded with 2 items as RNR and TND ranging from 0.542 to 0.770 and item 6 is also loaded with 2 items as HNS and PAP ranging from 0.885 to 0.895 . As per the opinion of the researcher, names of the factors are as follows:

Factor 1: $\quad$ Service charge, Bonus and Salary

Factor 2: $\quad$ Flexible rule \& regulation, Career development programs, Reward \& recognition and Working hours

Factor 3: $\quad$ Relationship with colleagues, Relationship with Supervisor and Relationship with subordinate

Factor 4: Workload, Work pressure, Empowerment \& status

Factor 5: $\quad$ Training \& development and Right \& responsibility

Factor 6: $\quad$ Performance assessment policy and Health \& safety

Based on the result of factor analysis, the following proposed research model has been developed. 

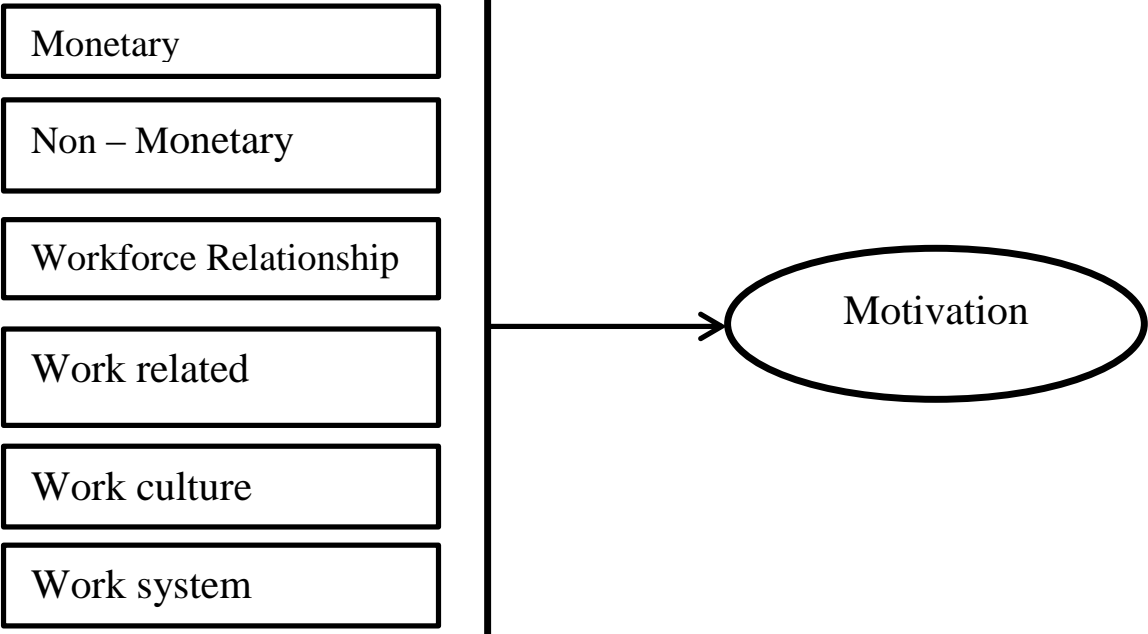

Figure 01: Proposed Study Model

Source: Author

\section{Conclusion}

The study attempted to examines the significant factors of motivation among the non-managerial staffs working in the hotel sector. Based on the result of data several importance factors are explores. It revealed that items are group into six factors. The findings of the study shows that service charge, bonus, salary, flexible rule and regulation, career development programmes, workload, work pressure, empowerment \& status, relationship with colleague, relationship with supervisor, relationship with subordinates, training \& development, working hours, performance assessment policy, health \& safety, reward \& recognition, right \& responsibility are the most significant factors which influences motivation among the non-managerial staff in the hotel sector. The coefficient values of $.963, .959$ and .949 suggest that service charge, bonus and salary are highly correlated with factor 1 . It suggests that management should give attention on the monetary factors of motivation in order to motivate non-managerial hotel staff. The coefficient value of 1.025 suggests that workload is highly correlated with factor 4 as well as flexible rule \& regulation, career development programs are highly correlated with factor 2 . Therefore, researcher suggests that management 
should be given much attention in these dimensions in order to attract and retain non-managerial hotel staff along with those monetary factors.

\section{References}

Ajang, P. E. (2007), “Assessing the Role of Work Motivation on Employee Performance", Available at: http://umu.diva-portal.org

Gichure, C.N. (2014), Factors Influencing Employee Motivation and its Impact on Employee Performance: A Case of Amref Health Africa in Kenya, MBA thesis, United States International University, Africa.

Gupta, B. \& Subramanian. J. (2014), Factors Affecting Motivation among Employees in Consultancy Companies, International Journal of Engineering Science Invention, Vol. 3, No. 11.

Ismajli, N., Zekeri, J \& et. Al. (2015), The Importance of Motivation Factors on Employee Performance in Kosovo Municipalities, Journal of Public Administration and Governance, Vol 5. No.1.

Jasmi, S. (2012), A study on Employees Work Motivation and its Effect on their Performance and Business Productivity, (MSc thesis), The British University, Dubai.

Jayala, R. (2016), Sri Lanka targets $4.5 \mathrm{~m}$ tourist arrivals by 2020. Sunday observer, Sunday, 13 March 2016.

Miththapala, S. (2015), Number of Hotel Rooms in Sri Lanka - Too Little or Too Many. Available at: https://www.linkedin.com.

Safiullah, A. (2015), Employee Motivation and its Most Influential Factors: A study on the Telecommunication Industry in Bangladesh. World Journal of Social Sciences, Vol. 5. No.1.

Senewiratne, H. (2016), 'Sri Lanka's hotel sector starved of skilled staff'. Available at: http://www.island.lk/index.

Turner, R. (2015). The authority on world travel \& tourism. World travel \& tourism Council. Available at: https://www.wttc.org.

Velnampy, T. (2007), Factors Influencing Motivation: An Empirical Study of Few Selected Sri Lankan Organizations. Available at: https:// www.researchgate.net/publication/255180324. 